\title{
WATER, SANITATION AND COVID-19 IN THE AMAZON
}

\author{
J. S. DA COSTA ${ }^{1}$, L. DE S. RODRIGUES ${ }^{2}$, A. G. C. DA SILVA ${ }^{3}$, R. A. NETO ${ }^{4}$, I. H. BATISTA ${ }^{5}$, C. C. DE \\ ALBUQUERQUE ${ }^{6}$, M. DA G. G. DE MELO ${ }^{7}$, M. A. R. LIBERATO ${ }^{8}$ \\ Universidade do Estado do Amazonas ${ }^{1,2,3,4,5,6,7,8}$ \\ ORCID ID: https://orcid.org/0000-0001-5318-2213 ${ }^{1}$ \\ jamersonjsc@yahoo.com.br ${ }^{1}$
}

Submetido 22/07/2020 - Aceito 25/09/2020

DOI: $10.15628 /$ holos.2020.10803

\begin{abstract}
Several studies on the pathophysiological and epidemiological characteristics of SARS-CoV-2 indicate the extracorporeal viability of the virus and the possibility of faecal-oral transmission through contaminated natural water and wastewater, suggesting a potential risk of spreading in socially vulnerable areas, such as the Brazilian Amazon, where access to sanitation and health services is lacking. Thus, an attempt we made to outline an overview of sanitation in the Brazilian Amazon and its possible impacts on the most vulnerable populations and
\end{abstract}

on the health system in a pandemic situation, based on bibliographic and documentary review and exploratory analysis of data related to basic sanitation and health. The Amazon has a huge deficit in sanitation and in the structure of health services, especially in rural areas, increasing the risk of spreading infectious diseases such as COVID-19, whose progress has placed some of the Amazonian states in a prominent position in the rankings of incidence and mortality.

KEYWORDS: coronavírus, sewage, transmission, vulnerability.

\section{ÁGUA, SANEAMENTO E A COVID-19 NA AMAZÔNIA}

\section{RESUMO}

Diversos estudos acerca das características fisiopatológicas e epidemiológicas do SARS-CoV-2 indicam a viabilidade extracorpórea do vírus e a possibilidade de transmissão fecal-oral, por águas naturais e residuais contaminadas, sugerindo potencial risco de propagação em áreas socialmente vulneráveis, como a Amazônia brasileira, onde o acesso aos serviços de saneamento e de saúde são deficitários. Assim, buscou-se traçar um panorama do saneamento na Amazônia brasileira e seus possíveis impactos sobre as populações mais vulneráveis e sobre o sistema de saúde em situação de pandemia, com base em revisão bibliográfica e documental e na análise exploratória de dados relativos ao saneamento básico e à saúde. A Amazônia apresenta um enorme deficit de saneamento e de estrutura dos serviços de saúde, especialmente em áreas rurais, elevando o risco de disseminação de doenças infecciosas como a COVID-19, cujo avanço tem colocado alguns dos estados amazônicos em situação de destaque nos rankings de incidência e mortalidade.

PALAVRAS-CHAVE: coronavírus, esgotamento sanitário, transmissão, vulnerabilidade. 


\section{INTRODUCTION}

Environmental health is a condition for promoting public health, improving the population's quality of life, preventing, and controlling infectious diseases. This aspect relates to access to basic sanitation, that is, services, infrastructures and operational facilities for water supply, sewage collection and treatment, urban cleaning and solid waste management, in addition to drainage and management of urban rainwater.

The absence or insufficiency of sanitation services, especially with regard to the promotion of drinking water supply and the collection and adequate treatment of sanitary sewers, directly affects the health of the population, increasing the spread of viral, bacterial and parasitic diseases, especially in urban and periurban areas, where these services are even more precarious or simply non-existent. Contaminated excrement or wastewater that is discharged into deficient sanitation systems or into natural water bodies can aggravate epidemiological situations.

According to Silva et al. (2019), approximately $25 \%$ of the world population does not have access to adequate environmental and sanitary conditions, such as sanitation and housing services, which puts them in a vulnerable situation in outbreak and epidemic scenarios. This is because changes in the quality of water resources due to health problems immediately reflect the progression of transmission in epidemiological occurrences of infectious diseases.

The specific legislation (Law No. 11,445/2007) and in the legal framework of related areas (National Water Resources Policy - Law No. 9,433/1997; National Environment Policy - Law No. 6,938/1981; and Law No. 8,080/1990, which provides for the promotion, protection and recovery of health and corresponding services) ensures universal access to sanitation services. Despite that, the distribution of these services occurs in an unbalanced manner among the different regions of Brazil (Pereira et al., 2020). In general, the Amazon region, which encompasses the entire North region plus the state of Mato Grosso and part of Maranhão, has unfavourable indicators as regards water supply and access to sanitary and sewage infrastructure, when compared to other regions from the country.

Regardless of the more comprehensive concept of basic sanitation provided for in the legislation, for the purposes of this study, we would approach the components of water supply and sanitary sewage. In addition to being an important indicator of a country's level of development, sanitation is an indispensable aspect of health promotion, especially in reducing hospitalizations and mortality from infectious diseases, notably those related to water and excreta.

Thus, this study aims to analyse the situation of access to drinking water supply and sewage collection in the Amazon region, presenting an overview of basic sanitation in a pandemic scenario of COVID-19 and the possible risk of transmission of the new coronavirus (SARS-CoV-2) through contaminated natural water and wastewater. 


\section{MATERIAL AND METHODS}

This study starts initially from a literature review that, according to Gil (2008), makes use of materials already published, mainly scientific articles. We also conducted an exploratory survey of basic sanitation data from the National Continuous Household Sample Survey (in Portuguese: PNAD Contínua - Pesquisa Nacional por Amostra de Domicílio Contínua), for the year 2019, carried out by the Brazilian Institute of Geography and Statistics (in Portuguese: IBGE - Instituto Brasileiro de Geografia e Estatística, 2020c); and data on the health system and the advancement of COVID19 from the Ministry of Health (Brasil, 2020a; 2020b; 2020c).

The Continuous PNAD is an integrated household survey of data production by probabilistic sampling carried out quarterly by Brazilian Institute of Geography and Statistics (IBGE), using the household rotation scheme 1-2(5) in which there is an interview at home in one month and its leaves the sample for two consecutive months, this sequence being repeated five times (IBGE, 2020a). The disclosure of cyclical information about trends and fluctuations in the workforce in Brazil occurs quarterly. As for the indicators on the general characteristics of households and residents, among which are those related to water supply and sewage, used in this study, their disclosure occurs annually. According to the IBGE (2020a), PNAD Contínua 2019 investigated 211,344 households each quarter, covering the entire national territory. This ensures greater precision of the estimates, especially in states with less population density and in rural areas, which are striking characteristics in regions such as the Amazon.

In the analysis of the situation of basic sanitation in the Amazon region, we used the indicators: water supply and sewage, which deal with the source of the water used in the households and the classification of the excreta drainage, respectively (IBGE, 2020a). The variables used were the percentage distributions of residents in households, by main source of water supply and by type of sanitary sewage.

We do not use sewage treatment indicators to illustrate the depletion scenario, as these indicators do not actually reflect this component of sanitation, since they are calculated considering the small portion of what is collected, as pointed out by National Water Agency (in Portuguese: ANA - Agência Nacional de Águas, 2017). Furthermore, the collection and availability of data on sanitation in the Amazon is not an easy task. Santiago et al. (2019) affirm that the little existing information is disperse among the various data generating entities. This reinforces the importance of PNAD Contínua as a data source for this region.

Despite other national sources of sanitation data, we chose to portray the sanitation situation in the Amazon from PNAD Contínua data. This is due to its (annual) periodicity and the standardization of information research and statistical data analysis, since as Getúlio Vargas Foundation (in Portuguese: FGV - Fundação Getúlio Vargas, 2018) points out the absence of these elements would make it difficult to outline an adequate panorama of access to basic sanitation water supply and sanitation. 


\section{RESULTS AND DISCUSSION}

\subsection{The COVID-19 pandemic - the virus and forms of contagion}

The city of Wuhan, Hubei province, China, accumulated, on December 31, 2019, 27 cases of pneumonia of unknown aetiology. Most frequently, patients had clinical symptoms such as dry cough, dyspnoea, fever and bilateral pulmonary infiltrations. The causative agent was isolated and identified on January 7, 2020, and called Serious Acute Respiratory Syndrome Coronavirus 2 (SARSCoV-2) (Sohrabi et al., 2020).

Coronavirus disease 2019 (COVID-19), as it was called by the World Health Organization (WHO), develops without major damage to the health of most individuals. However, some develop fatal complications, including organ failure, septic shock, pulmonary oedema, severe pneumonia and severe acute respiratory syndrome (SARS), especially those older patients and/or those with comorbidities (cardiovascular, cerebrovascular, endocrine, digestive and respiratory diseases), leading them to require intensive care (He et al., 2020).

With the exponential increase in the number of cases, the World Health Organization declared, on January 30, 2020, the Chinese outbreak as a Public Health Emergency of International Interest, with high risk for countries with vulnerable health systems. The WHO also indicated the need to adopt measures for early detection, isolation and immediate treatment of patients, in addition to strengthening health systems, combating misinformation and the economic impacts caused by the virus (Velavan \& Meyer, 2020). It is noteworthy that even countries with a strong hospital structure, such as Spain, Italy, England and the United States, are facing immense challenges to contain the impacts on the health system resulting from the progress of the disease, with a large number of contaminated and dead in these countries.

The epidemic of the new coronavirus expanded from Wuhan to all of China and was exported to almost all countries in the world, initially as imported cases and, later, passing to sustained or community transmission (Lipsitch et al., 2020). On March 13, 2020, the WHO declared the COVID-19 pandemic. As Rodriguez-Morales et al. (2020), Latin America remained free of COVID-19 cases until February 25, 2020, when Brazil registered the first case, in the city of São Paulo. Since then, cases have been progressively increasing and changing their distribution dynamics across the country. Initially, with a concentration of cases in the Southeast and South regions, with the advance of the disease in Brazil, the states of the North and Northeast regions started to be among the first in the country in terms of COVID-19. On the 20th March 2020, the Ministry of Health declared community transmission throughout the national territory.

With the growing number of studies on the pathophysiology characteristic of COVID-19, we gradually come to know the mechanisms of the virus's spread, although there are still many gaps and the need for more robust studies. Consistently, we know that SARS-CoV-2 is a betacoronavirus, belonging to the subfamily Coronavirinae, of the Coronaviridae family, like other known coronaviruses. All of them are pleomorphic with simple RNA ribbon in a crown shape (He et al., 2020; Sahin et al., 2020; Wu et al., 2020a). Until the outbreak of Severe Acute Respiratory Syndrome, caused by SASR-CoV, in China between the years 2002 and 2003; and the Middle East 
Respiratory Syndrome, caused by MERS-CoV, in 2013, coronaviruses were not considered pathogenic for humans (Sahin et al., 2020).

Transmission occurs mainly through respiratory fomites in contact with the mucous membranes of the airways, mouth and eyes. After infection and replication inside the cells, SARSCoV-2 are released by exocytosis and can infect epithelial cells in the pulmonary alveoli, where they stimulate the main symptoms, in addition to kidney, liver, intestinal cells and T lymphocytes (He et al., 2020; Velavan \& Meyer, 2020). Further to the immediate contact of the respiratory droplets with the mucous membranes, in a direct transmission, contagion can also occur through the contact of the hands with contaminated surfaces, which subsequently meet the face.

In this sense, studies such as Van Doremalen et al. (2020) have evaluated the stability of SARS-CoV-2 in aerosols and surfaces (plastic, stainless steel, copper and cardboard). The results showed that SARS-CoV-2 remained viable in aerosols for up to 3 hours (with a half-life of around 1.1 to 1.2 hours). The new coronavirus was more stable in plastic and stainless steel than in copper and cardboard, remaining viable on those surfaces for up to 72 hours ( 3 days). As for the other surfaces, on copper, SARS-CoV-2 remained viable for up to 4 hours, while on cardboard, the permanence was up to 24 hours.

According to Wang et al. (2020), several factors can influence the transmission by coronavirus, including climatic conditions (such as temperature and humidity), population density and quality of medical care. Therefore, understanding the relationship between the climate and transmission of COVID-19 can help predict the intensity and duration of this pandemic. According to the authors, indirect evidence showed that, until March 22, 2020, non-tropical countries with low temperatures and low relative humidity recorded $90 \%$ of COVID-19 cases.

The study by Wang et al. (2020) however assessed the intensity of transmission in different climatic conditions in a single country, China. Their conclusions assume that the high temperature and the high relative humidity of the air reduce the transmission of COVID-19, similar to what occurs with other respiratory viruses, such as influenza. In addition to the direct effect of climatic factors on the physiology of the virus, the authors also indicate the possibility of weakening host immunity in colder and drier climates, making them more susceptible to infection, as an alternative mechanism for increasing the transmission of COVID-19 in these regions.

In contrast, a survey by Harmooshi et al. (2020) points out divergences between the several studies that have been developed in this regard, some corroborating what Wang et al. (2020), others warning about the greater resistance of SARS-CoV-2 in an environment with high temperature and humidity, than other coated viruses. Anyway, so far, there is no direct evidence of the influence of temperature and humidity on the transmission of the new coronavirus. The fact is that neither the high temperatures of the Brazilian Northeast nor the heat associated with high relative humidity in the Amazon have prevented the advance of SARS-CoV-2, placing the States of Amazonas, Amapá, Acre, Roraima and Maranhão among those with higher COVID-19 incidence and mortality rates in Brazil (Figures 1 and 2, respectively).

Barrozo et al. (2020), through the Monitora-Clusters Project, whose objective is to monitor the high-risk active spatial and space-time clusters in the national territory during the course of the epidemic, as a powerful tool in helping to make health structure management decision-making , 
identified clusters at high risk of death, including the states of Amazonas and Maranhão. As of April 22, the North Region emerged as the new and most significant grouping of cases and deaths, corroborating the Amazon region as an important focus for the dissemination of COVID-19. The studies by França (2020), Gois et al. (2020), Ribeiro et al. (2020) and Rodrigues and Rodrigues (2020) also indicate the high risks of incidence and mortality in the North Region of Brazil.

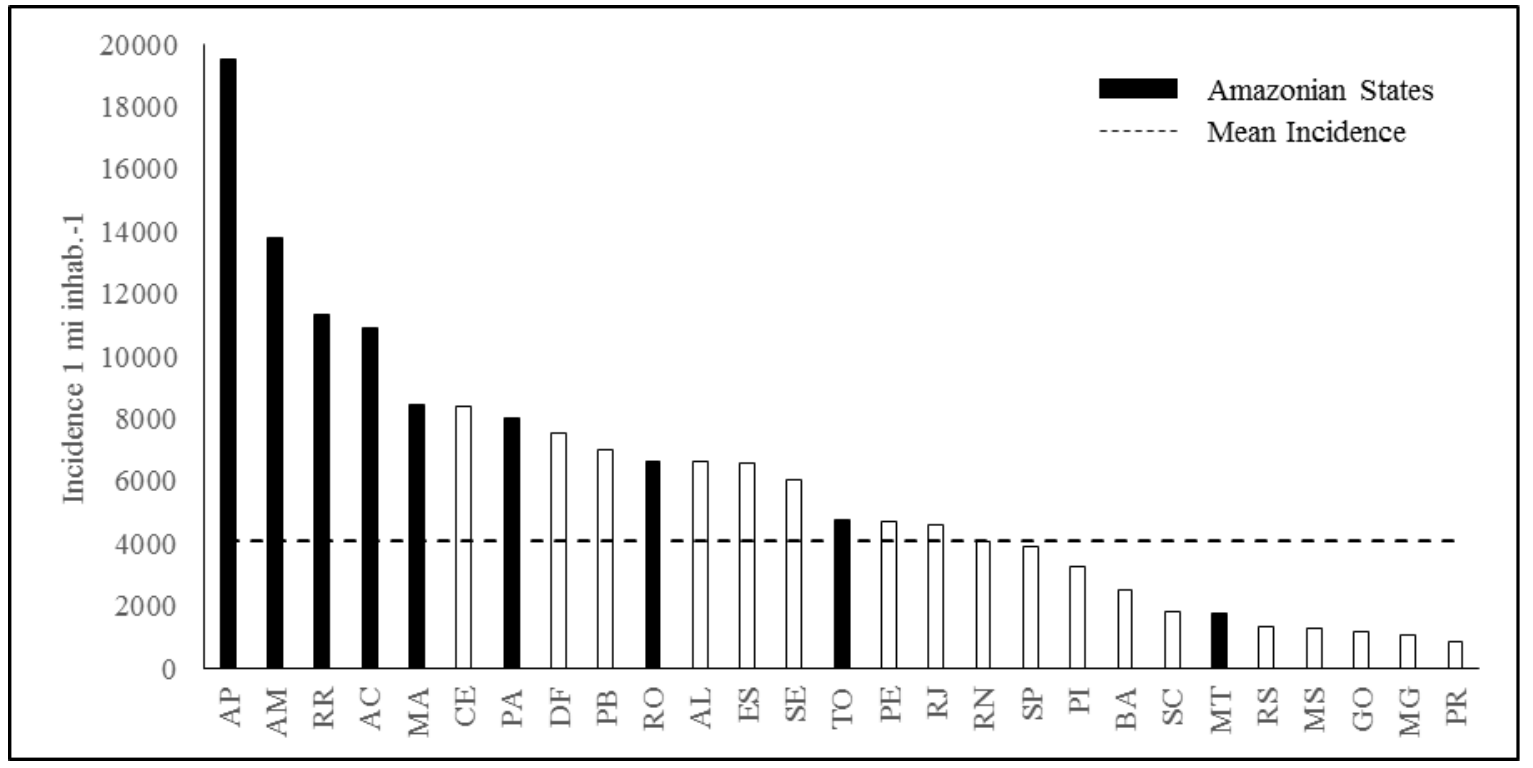

Figure 1: Incidence coeficiente for COVID-19 - Brazil (June 15, 2020).

Source: Own elaboration based on the analysis of Ministry of Health data (Brasil, 2020c).

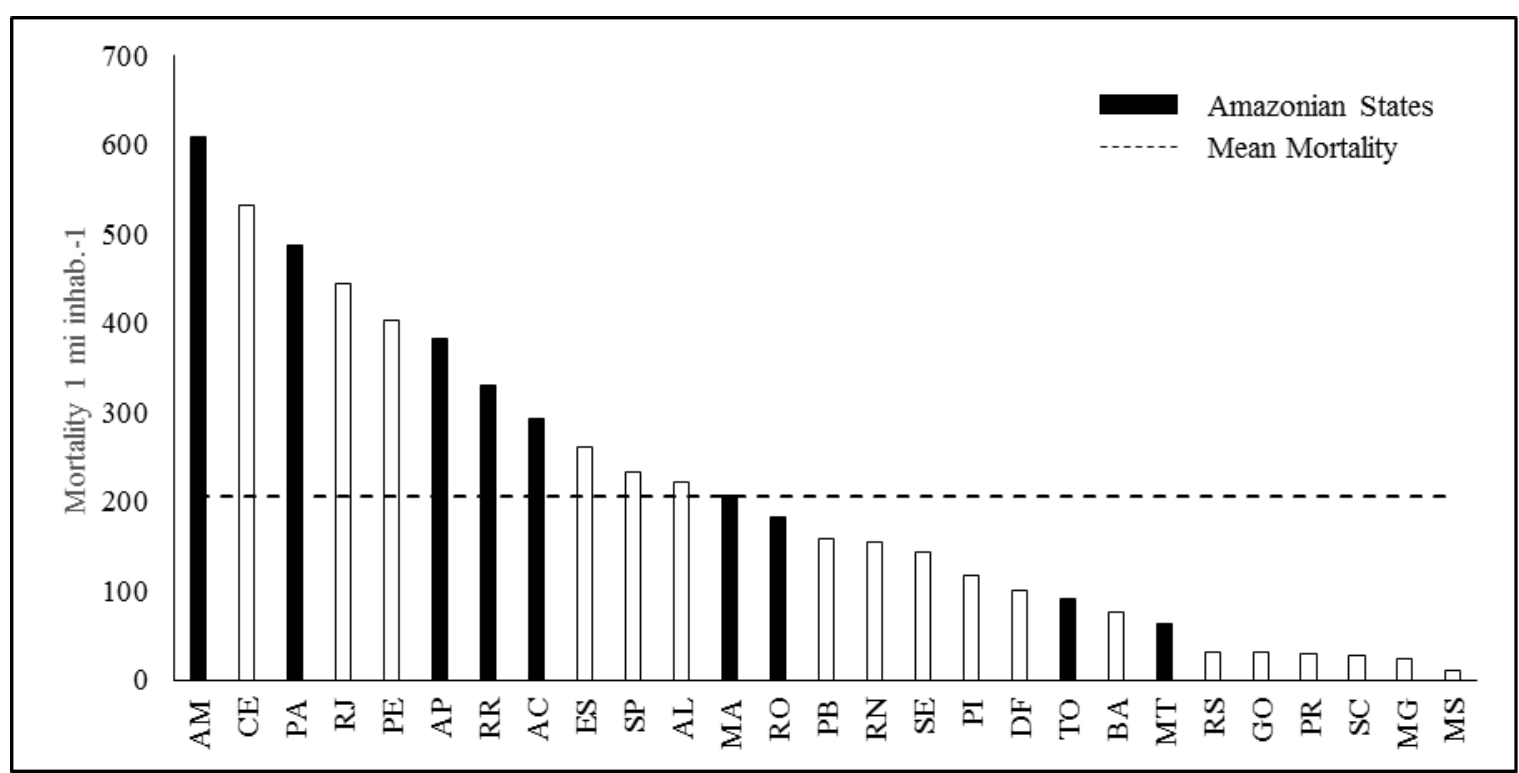

Figure 2: Mortality coefficient for COVID-19 - Brazil (June 15, 2020).

Source: Own elaboration based on the analysis of Ministry of Health data (Brasil, 2020c).

Respiratory viruses are usually more contagious when a patient is symptomatic (Sahin et al., 2020). However, the most recent studies (He et al., 2020; Lipsitch et al., 2020; Rothe et al., 2020; Wu et al., 2020a) point out that the transmission of SARS-CoV-2 may be occurring during the COVID-19 asymptomatic incubation period, estimated between 2 and 10 days. Thus, in addition to 
hand and environment hygiene, measures of social distance and isolation of those symptomatic patients have gained emphasis, as well as the use of personal protective equipment (PPE), such as masks (Wu et al., 2020a). Despite the impact of these measures on the population's social and economic well-being, they are justified, since young people are important sources of transmission (Lipsitch et al., 2020).

For Rodriguez-Morales et al. (2020), despite all these coordinated measures, which have been widely adopted in the most diverse countries, on all continents, in regions with a low Human Development Index (HDI), the outbreak of COVID-19 may be even more devastating than in developed countries, such as the United States and European countries. And here, it should be noted that, although Brazil has a high HDI (0.727), in the North region, which corresponds to most of the territory of the Brazilian Amazon, according to data from the Atlas of Human Development in Brazil 2013, 65.7\% municipalities have low or very low HDI (Ipea, 2013).

These data indicate among other things an inefficiency of social development policies, and even if efforts to prepare for coping with COVID-19 are required, their health systems are not sufficiently prepared. These systems can be overwhelming due to the common outbreaks of vector-borne diseases and water-related and excreta-related illnesses, reflecting the lack of sanitation (Rodrigez-Morales et al., 2020). In this context, the simple possibility of transmission of COVID-19 by contaminated natural water and wastewater raises major concerns.

\subsection{Possibility of transmission by contaminated water and sewage}

The number of studies that indicate the stable permanence of SARS-CoV-2 in the feces and urine of COVID-19 patients is increasing, even when the virus is no longer detected in the respiratory tract, suggesting the possibility of transmission by contaminated human excrement. Repici et al. (2020) observed the viability of the new coronavirus for up to two days. Wu et al. (2020b), registered positive results for SARS-CoV-2 in stool samples for eleven days (on mean) after patient discharge. There was a positive correlation of these numbers with the existence of gastrointestinal symptoms, however there was no connection with the severity of the patients' condition, that is even individuals with mild or even asymptomatic symptoms can be sources of infection (Gu et al., 2020; Wang et al., 2020; Yeo et al., 2020).

These results and information on the viability of other coronaviruses (e.g., SARS-CoV and MERS-COV) in the environment have led to the development of research that evaluates the viability of the COVID-19 virus in natural and wastewater, such as those published by Gormley et al. (2020), Holshue et al. (2020), Husman and Lodder (2020), Meng et al. (2020), Naddeo and Liu (2020), which can represent a risk to the health of populations, especially in areas with poor or non-existent sanitation conditions (Husman \& Lodder, 2020; Yeo et al., 2020). The risk does not exist only in direct contact with these contaminated waters or sewers. According to Meng et al. (2020), transmission can also occur through aerosols generated by the discharge of these materials in sanitary pipes or by their dumping and handling.

Overall, drinking water supply systems offer protection against infectious diseases, including COVID-19 (Husman \& Lodder, 2020). According to the WHO (2020), there is no evidence of transmission of the new coronavirus through drinking water, distributed through the supply 
systems. However, in realities such as the Amazon, where a significant portion of the population does not have access to the drinking water supply service and directly uses natural (untreated) water, as will be seen in more detail below, the vulnerability to transmission COVID-19 should be considered and monitored.

This scenario of deficit in sanitation services is even more alarming when considering the collection and treatment of sewage and solid waste. As stated by Husman and Lodder (2020), Meng et al. (2020) and Yeo et al., 2020, the contamination of water by sewage from sick individuals can work as an important transmission route for COVID-19. The presence of SARS-CoV-2 viral load in these environments can increase considerably, due to the pandemic state to which we are currently subjected and, consequently, to the implementation of temporary health equipment (field hospitals), since even the permanent services, mostly in Latin America, do not have wastewater treatment plants (ITB, 2020).

According to the WHO (2020), there is still no evidence of the viability of SARS-CoV-2 in surface or underground sources of freshwater, although Husman and Lodder (2020) recorded the survival of this virus in taps with non-chlorinated water in Holland hospitals. Viruses that cause other infectious diseases related to water and excreta, such as hepatitis A, for example, can survive for up to ten weeks depending on environmental conditions (Husman \& Lodder, 2020). The degradation of the quality of natural waters resulting from the absence or precariousness of sewage collection and treatment services impacts the uses downstream of the sources of contamination (supply, bathing, irrigation, among others) and the health of the population. Despite the low risk of contagion of COVID-19 through sewage systems, it is necessary to consider it, especially in Brazil, where the disinfection of the portion of the sewage that is treated has not been performed since it is not required (ITB, 2020).

Nascimento (2020) addresses another concern: the risk of contamination of groundwater in areas close to cemeteries where the corpses of those killed as a result of COVID-19 are buried. As the author argues, the new coronavirus remains active for days in the body, even after death, which is why there are a series of recommendations from the Ministry of Health to be followed by funeral professionals and families, for the burial of these people. In this sense, since there is already a record of microbiological contamination of groundwater due to necro-leachate, the risk is also assumed for SARS-CoV-2 (Nascimento, 2020).

The progressive increase in the number of deaths in areas with a deficit in sanitation services raises this risk. The Amazon region presents, in addition to inadequate basic sanitation conditions, yet another factor of aggravation in these situations that is the shallow depth of the mean water table level (Brito et al., 2020). Despite facilitating the capture, this aspect contributes to the contamination of these waters (Franco \& Arcos, 2020). It is important to understand that although there is great surface water availability, underground sources play an important role in supplying Amazonian populations, especially those not served by drinking water supply services (Brito et al., 2020).

If on one side the circulation of SARS-CoV-2 in waste and natural waters (recipients of raw or treated sewage) represents a health risk; on other side, the monitoring of these environments, at strategic points, can serve as a surveillance system, indicating the circulation of the virus in areas 
without record of cases, as already applied to other viruses (Lodder et al., 2013; Husman \& Lodder, 2020). This evidence may be based on precautionary measures, such as those published by the WHO (2020), and to combat COVID-19 including the mapping and signaling of inappropriate places, to avoid consumptive or non-consumptive uses of primary contact - recreation.

In this perspective, the ANA and the National Institute of Science and Technology in Sustainable Sewage Treatment Plants (in Portuguese: INCT ETEs Sustentáveis - Instituto Nacional de Ciência e Tecnologia em Estações Sustentáveis de Tratamento de Esgoto), in partnership with other government institutions, have been monitoring sewage in the cities of Belo Horizonte and Contagem, through the Monitoramento Covid Esgostos pilot project. The initial results of this monitoring showed the presence of SARS-CoV-2 in 59.7\% of the samples collected in the first six weeks, but as of the eleventh week, all monitored sites tested positive for the new coronavirus (INCT ETEs Sustentáveis, 2020a; 2020b). It was also found that the increase in the number of contaminations was compatible with the increase in the percentages of positive samples per subbasin, as well as the reverse, the reduction of infections in the sub-basins where the number of contaminated samples regressed. As expected, it is possible to understand the prevalence and dynamics of circulation of the new coronavirus in the region, and build models that assist in the establishment of trends of spread of the disease, subsidizing the definition of strategies for coping.

\subsection{Overview of basic sanitation in the Amazon}

Despite advances in regional development in the Amazon, Silva (2015) emphasizes that State actions in this regard have lost importance, especially in the last decade. As a result, it began to adopt planning based on regionalized public policies (e.g., Sustainable Amazon Plan). However, the heterogeneity of the Amazonian space requires proposals for socioeconomic development and improvement of the population's quality of life based on multiscale, multidimensional and transversal perspectives (Mourão \& Silva, 2018).

According to data from the Regional Development Plan for the Amazon (in Portuguese: PRDA - Plano Regional de Desenvolvimento da Amazônia) 2020-2023, the Brazilian Amazon covers 5.1 million $\mathrm{km}^{2}$, which corresponds to $59.1 \%$ of the national territory, where more than 28 million people live, of which $72 \%$ in urban areas. In addition to the thousands of riverside communities, the region is also home to 180 native peoples with an estimated population of 306,000 indigenous people; and 1,206 remaining quilombo communities (IBGE, 2020b; SUDAM, 2020). The vast territory and low population density increase the development challenges, resulting in poor infrastructure and high social vulnerability of the populations (Portugal \& Silva, 2018).

This vulnerability is evident, for example, when it comes to sanitation. References to the Amazon usually exalt water abundance in addition to forests. What most Brazilians are unaware of or neglect is that a large portion of the Amazonians does not have access to basic sanitation services. According to data from the PNAD Contínua 2019 (Table 1), while the mean number of residents supplied by the general drinking water distribution network in Brazil is $78.9 \%$, in the Amazon, this index is only $65.9 \%$ (IBGE, 2020c). The $34.1 \%$ deficit in the provision of public drinking water services is supplied through deep or shallow wells (28.9\%), springs (2.7\%) and other sources 
$(2,4 \%)$, such as rainwater, rivers and streams, lakes, weirs and water trucks (IBGE, 2020c), without any control or guarantee of the quality and potability of this water.

França (2020) and Rodrigues and Rodrigues (2020) analyzing the health and epidemiological profile of the Paraense Amazon, also based on data from IBGE, Institute of Applied Economic Research (in Portuguese: Ipea - Instituto de Pesquisa Econômica Aplicada), Trata Brasil Institute and health agencies, found the importance of the universalization of water supply services for coping with COVID-19. They concluded that both Pará and the North Region are well below the national average in relation to the percentage of the population with access to drinking water supply. Tavares and França (2020), strictly analyzing the situation in the capital Belém, observed that although $75.2 \%$ of households have access to the public drinking water supply network, the water supply is not daily. Because of this, these populations resort to unsafe water sources (e.g. wells, rainwater) during intermittent periods, as do those who do not have access to the public network. The irregular supply of potable water and the recurrent use of raw water make it difficult to adhere to simple hygiene recommendations (Ribeiro et al., 2020; Tavares \& França, 2020).

Table 1: Percentage distribution of residents in households by main source of water supply in the Amazon - 2019.

\begin{tabular}{lccccc}
\hline \multirow{2}{*}{ Locality } & \multicolumn{4}{c}{ Distribution by main source of water supply (\%) } \\
\cline { 2 - 6 } & $\begin{array}{c}\text { General } \\
\text { Network }\end{array}$ & Deep Well & $\begin{array}{c}\text { Shallow } \\
\text { Well }\end{array}$ & Source & Others \\
\hline Acre & 54.6 & 15.9 & 18.8 & 6.9 & 3.9 \\
Amapá & 54.3 & 30.0 & 11.0 & 0.5 & 4.3 \\
Amazonas & 72.2 & 14.0 & 2.5 & 5.4 & 5.9 \\
Maranhão & 69.2 & 20.1 & 8.2 & 1.2 & 1.3 \\
Mato Grosso & 80.5 & 11.5 & 5.6 & 1.7 & 0.6 \\
Pará & 49.3 & 28.3 & 15.3 & 1.9 & 5.2 \\
Rondônia & 44.5 & 19.2 & 33.7 & 2.5 & 0.1 \\
Roraima & 86.6 & 3.4 & 9.2 & 0.5 & 0.3 \\
Tocantins & 81.9 & 6.4 & 7.3 & 4.1 & 0.3 \\
\hline Amazon (Mean) & $\mathbf{6 5 . 9}$ & $\mathbf{1 6 . 5}$ & $\mathbf{1 2 . 4}$ & $\mathbf{2 . 7}$ & $\mathbf{2 . 4}$ \\
\hline Brazil (Mean) & $\mathbf{7 8 . 9}$ & $\mathbf{1 0 . 0}$ & $\mathbf{5 . 9}$ & $\mathbf{2 . 2}$ & $\mathbf{3 . 0}$ \\
\hline
\end{tabular}

Source: Continuous National Household Sample Survey (PNAD Contínua, in Portuguese) (IBGE, 2020c).

The data related to sanitary sewage are even more alarming, as shown in Table 2. In Brazil, the mean number of residents with sewers connected to the general sewage system is $49.8 \%$. In the Amazon, this average is only $29.8 \%$. The most significant portion of the residents $(70.2 \%)$ have no connection to the sewage collection network, with their excreta drained to septic tanks (42.1\%) or, in the worst situation, to ditches, rudimentary pits, water bodies and other forms of drains, as do $28.1 \%$ of these residents (IBGE, 2020c). The studies by Gois et al. (2020), Rodrigues and Rodrigues (2020) and Tavares and França (2020) corroborate our results.

Table 2: Percentage distribution of residents in households by type of sewerage in the Amazon - 2019.

\begin{tabular}{|c|c|c|c|c|}
\hline \multirow[b]{2}{*}{ Locality } & \multicolumn{4}{|c|}{ Distribution by type of sewerage (\%) } \\
\hline & $\begin{array}{l}\text { General } \\
\text { Network }\end{array}$ & $\begin{array}{l}\text { Septic tank } \\
\text { connected to the } \\
\text { general network }\end{array}$ & $\begin{array}{c}\text { Septic tank } \\
\text { disconnected to the } \\
\text { general network }\end{array}$ & Others \\
\hline Acre & 35.9 & 2.7 & 22.2 & 39.2 \\
\hline Amapá & 12.1 & 5.3 & 51.1 & 31.5 \\
\hline HOLOS, & 2020 & & & 10 \\
\hline
\end{tabular}




\begin{tabular}{|c|c|c|c|c|}
\hline \multirow[b]{2}{*}{ Locality } & \multicolumn{4}{|c|}{ Distribution by type of sewerage (\%) } \\
\hline & $\begin{array}{l}\text { General } \\
\text { Network }\end{array}$ & $\begin{array}{l}\text { Septic tank } \\
\text { connected to the } \\
\text { general network }\end{array}$ & $\begin{array}{c}\text { Septic tank } \\
\text { disconnected to the } \\
\text { general network }\end{array}$ & Others \\
\hline Amazonas & 34.5 & 9.1 & 27.2 & 29.2 \\
\hline Maranhão & 16.7 & 5.3 & 52.5 & 25.5 \\
\hline Mato Grosso & 31.0 & 7.8 & 49.8 & 11.3 \\
\hline Pará & 11.5 & 6.4 & 50.1 & 32.0 \\
\hline Rondônia & 7.4 & 8.3 & 57.5 & 26.8 \\
\hline Roraima & 28.4 & 9.4 & 34.4 & 27.7 \\
\hline Tocantins & 26.0 & 10.1 & 33.7 & 30.1 \\
\hline Amazon (Mean) & 22.6 & 7.2 & 42.1 & 28.1 \\
\hline Brazil (Mean) & 43.2 & 6.6 & 30.2 & 19.9 \\
\hline
\end{tabular}

Source: Continuous National Household Sample Survey (PNAD Contínua, in Portuguese) (IBGE, 2020c).

According to Varela et al. (2020), despite the greater percentage of the population with access to the general drinking water distribution network, the health risks of those who do not have this service increases, due to the lack of access to sewage collection and treatment services, already that sanitary effluents end up coming into direct or indirect contact with surface or underground waters that are used for supply. In other words, favouring one or the other component of basic sanitation does not efficiently result in improving the quality of the population's health. There must be a balance in access to all services that make up basic sanitation. In this same sense, Jardim and Buckeridge (2020) also point out that the promotion of public policies that address only one of the factors will not solve the high vulnerability to events of this magnitude, being necessary strategies must contemplate different degrees of influence and different factors, simultaneously.

Portugal and Silva (2018) attribute this panorama to the lack of investments in sanitation infrastructure adequate to the local reality, in view of its high cost and the possibility of using the dense hydrographic network that crosses the Amazonian cities, as a receiver and purifier of the tailings sanitary, and the direct capture of surface and groundwater. To illustrate this lack of investments to which the authors refer, we use information from the National Sanitation Information System (in Portuguese: SNIS - Sistema Nacional de Informações sobre Saneamento), whose data indicate that of the ten States with the lowest volume of investments in water and sewage services, between 2016 and 2018 , seven integrate the Amazon (Acre, Amazonas, Amapá, Pará, Rondônia, Roraima and Tocantins) (Brasil, 2019). Together, these States account for only $5.9 \%$ of total investments in the country; that is less than $1 \%$ each. This, even considering that some of these states had an increase of more than $50 \%$ and others doubled the values of investments in 2018 compared to data from 2017. The states of Rondônia and Roraima however had reductions of $-51 \%$ and $-21.2 \%$ in this comparison, respectively (Brasil, 2019).

In the case of rural areas in the Amazon, most households use different sources of water unrelated to the general public supply network. According to IBGE (2017), in the North Region only $17.67 \%$ of rural households were connected to the water distribution network, while $82.3 \%$ were supplied by other sources that also characterize situations of deficit, due to the no guarantee of quality and health safety, as ponders Lobão (2019). According to Melo et al. (2020), 33\% of rural populations do not have access to potable water supply and use other unsafe sources. The 
consumption or contact with raw water can become a privileged vehicle for the transmission of infectious diseases, especially in regions with lower socioeconomic development.

Regarding exhaustion, according to Neu et al. (2016), the largest portion of the rural Amazonian population still uses rudimentary cesspools, ditches and riverside areas, the rivers themselves as receptors for household sewage. The isolation and dispersion of these communities makes it difficult to implement general sewage collection and treatment networks. In addition to the topographically unfavorable location, as they are very low, riverside residences are still subject to the flood pulses of the rivers, which can compromise the construction of possible sanitary structures or even lead to the overflow of their content, as Tavares and França (2020) also suggest. This absence or inadequacy of basic sanitary infrastructure exacerbates the risks of fecal-oral contamination, responsible for the high rates of infectious disease among these populations (Neu et al., 2016; Le Tourneau et al., 2019).

When we evaluate the relationship between the participation of Brazilian macro-regions in terms of investments and lack of access to water supply and sewage, between 2014 and 2018, the North region that comprises more than $75 \%$ of the territory of the Amazon, in Brazil, presents extreme situation for both services. The deficit in water supply is 7.8 times greater than the investment. With regard to sewage, the deficit exceeds investments by $380 \%$ (Brasil, 2019). França (2020) reported a similar drop in investments in sanitation over the past ten years. She asserts this increases interregional disparities and inequalities and makes the North Region vulnerable in situations of epidemiological crises, such as that of COVID-19, and contributes significantly to the high incidence and mortality from SARS-CoV-2 infection in the region.

The precariousness of basic sanitation in the Amazon can inhibit or lead to the underdevelopment of important economic activities, especially those that depend on good environmental conditions, such as tourism whose potential is underutilized in some areas, due to this situation of sanitation deficit (SUDAM, 2020). However, it should be considered that actions to improve these services in the Amazon are challenging. According to Portugal (2018), the urban models applicable to most Brazilian cities, where natural coverage is increasingly smaller and the modal of transport is basically land based, it does not suit the largest tropical forest on the planet. For the Amazonian reality, it is necessary to think about alternative and low-cost solutions that connect urban and natural spaces, mixing terrestrial and aquatic mobility alternatives, as proposed by Neu et al. (2016).

Promoting access to sanitation services is closely linked to public health. The lack or inefficiency of basic aspects of sanitation exposes these populations to the most diverse infectious diseases, with an aggravation for those communities that live on the banks of contaminated rivers and streams, a common situation in Amazonian cities (SUDAM, 2020). According to data from the Ministry of Health, the states of the Amazon registered in 2018 a mean of 9,673 hospitalizations due to diseases associated with poor sanitation and a total of 322 deaths due to infectious gastrointestinal diseases (Table 3), the equivalent of 14, $8 \%$ of national occurrences (Brasil, 2020b). These data, which already stand out under normal circumstances, raise even more concern in the current pandemic scenario of COVID-19, in which there is evidence of the possibility of viral transmission through contaminated water and sewage, as previously discussed. 
In this perspective, the effort required by health systems worldwide by COVID-19 must be even greater in the Amazon. The high incidence of neglected tropical diseases (NTDs), such as malaria, Chagas disease, yellow fever, dengue, Zika and Chikungunya, as well as diseases related to water and excreta, of bacterial, helminth and viral origin, already demand attention largest health service in the region (SUDAM, 2020). The overload caused by the new coronavirus pandemic makes the health situation in the states of the Amazon even more disturbing. To get an idea of the situation, the data from May 2020 (Table 3) from the Ministry of Health indicate that the Amazon has 54,045 hospital beds which is equivalent to a mean of 1.89 beds for every 1,000 inhabitants (Brasil, 2020a). It should be noted that this amount is already the result of actions by states and municipalities to increase the availability of beds, such as the implementation of field hospitals.

Table 3: Panel on the number of hospitalizations for diseases* associated with lack of sanitation and the number of deaths due to infectious gastrointestinal waterborne diseases (2018); and hospital beds (May 2020).

\begin{tabular}{lcccc}
\hline Locality & Hospitalizations & Deaths & Total Beds & $\begin{array}{c}\text { Beds 1000 } \\
\text { inhab.-1 }\end{array}$ \\
\hline Acre & 1,257 & 09 & 1,559 & 1.77 \\
Amapá & 875 & 08 & 1,316 & 1.56 \\
Amazonas & 3,782 & 30 & 6,074 & 1.48 \\
Maranhão & 42,188 & 91 & 14,481 & 2.05 \\
Mato Grosso & 3,955 & 24 & 7,106 & 2.14 \\
Pará & 28,348 & 104 & 14,614 & 1.70 \\
Rondônia & 3,910 & 22 & 4,354 & 2.45 \\
Roraima & 1,051 & 21 & 1,515 & 2.50 \\
Tocantins & 1,692 & 3,026 & 2.08 \\
\hline Amazon (Total) & $\mathbf{8 7 , 0 5 8}$ & $\mathbf{3 2 2}$ & $\mathbf{1 3 4 , 0 4 5}$ & - \\
\hline Amazon (Mean) & $\mathbf{9 , 6 7 3}$ & $\mathbf{3 6}$ & - & $\mathbf{3}$ \\
\hline *Infectious gastrointestinal diseases (cholera, typhoid and paratyphoid fevers, shiguelose, amebiasis, \\
diarrhea and gastroenteritis of presumable infectious origin and other intestinal infections), yellow fever, \\
dengue, leptospirosis, malaria and schistosomiasis.
\end{tabular}

Source: Own elaboration based on the analysis of Ministry of Health data (Brasil, 2020a; 2020b).

When dealing with the Amazon, it is necessary to draw attention to the fact that these hospital beds are located in urban areas and concentrated in large urban centers (capitals and metropolitan regions), as rebounded by Guimarães et al. (2020) and Rodrigues and Rodrigues (2020). These authors recall that historically rural populations have not had favorable conditions for access to sanitation and health. In the case of Amazonian traditional populations (indigenous, quilombolas, agroextractive and riverside), logistical difficulties in accessing health services, such as the duration of trips by river (four hours on mean) and the costs of traveling, lodging and food increase the possibility of worsening health conditions and increase inequality in access to health in this region that is already very disadvantaged (Guimarães et al., 2020; Rodrigues \& Rodrigues, 2020).

According to the evaluation by Ribeiro et al. (2020), even in metropolitan cities in the North Region, hospitalized patients are at a higher risk of dying from COVID-19, compared to other regions of the country. Both the North and the Northeast regions have weaknesses in epidemiological and intensive care services, especially regarding the availability of beds and mechanical ventilation equipment, and the growing number of cases has caused cities in these 
regions to collapse in the health system, having Manaus as one of the worst examples (Ribeiro et al., 2020).

Thus, Naddeo and Liu (2020) affirm that developing regions are more vulnerable to the new coronavirus (SARS-CoV-2), not only due to the greater risk of contact with contaminated water, owing to the deficiency of drinking water supply systems and sanitation, but also because there is not enough investment in public health. These authors clarify that the globalization process essential to the development of nations likewise subjects them to new health risks, especially considering the expansion of mobility between countries with the free movement and free trade agreements. Therefore, developed nations should be responsible for providing economic and technological support to developing countries to improve sanitation systems as a means of selfprotection. In this way, the creation of an international fund for basic sanitation would be a very reasonable alternative, like other funds aimed at promoting sustainable development.

\subsection{Risks of basic sanitation deficit in a pandemic scenario}

Until further studies are completed or carried out on the rich potential of exposure to wastewater and recipients natural waters in the transmission of COVID-19, additional preventive measures must be strongly considered. As seen before, these possible transmission routes can be especially problematic in areas with inadequate sanitation and limited access to drinking water (Yeo et al., 2020). Aware of the risks, WHO has issued a series of practical care guidelines that go beyond social distancing (or isolation) and hand hygiene from domestic and hospital environments, measures for the collection, management and treatment of urban and rural sewage (WHO, 2020), in order to expand the fight against COVID-19, especially in the most vulnerable regions. These recommendations are being updated as knowledge about SARS-CoV-2 increases. Understanding the possible dissemination mechanisms can help to guide or adapt prevention actions.

Nevertheless, it should be noted that even the simplest hygiene measures basically require water and sewage, resources not available to the most socially vulnerable populations. According to Coelho et al. (2020), these populations are represented by regions that mix urban and rural populations with less infrastructure, such as most cities in the Northeast and the capital of the State of Amazonas, Manaus; rural areas of the northeastern Caatinga, where access to water and sewage services is precarious; and, in the worst situation of vulnerability, by the predominantly rural regions of the Amazon, where access to treated water and sewage collection are deficient. These areas are expected to suffer above average if preventive actions are not adopted quickly. This is because the spread of the disease would burden the difficulties that are already common for these populations (Coelho et al., 2020).

According to the classification proposed by Coelho et al. (2020) and with the statements of ANA (2017), Le Tourneau et al. (2019) and Pantojo et al. (2019), the Amazon is among the most vulnerable regions due to the deficit of essential services to improve health conditions and quality of life, such as drinking water supply and sanitation. This ranking, however, shows that not only inland cities have sanitation problems, but also capital cities, like Manaus (Coelho et al., 2020; Ribeiro et al., 2020). 
Macedo et al. (2020) emphasize that support and investment in public policies aimed at improving basic sanitation conditions in communities are essential to support health systems, to fight infectious diseases, and to reduce mortality. It is necessary to rethink and prioritize actions to strengthen the infrastructures for drinking water supply and sewage collection and treatment in these subalternized areas. These actions are a minimum condition for all citizens are entitled to, even more so in the view of the COVID-19 pandemic scenario. They are strategic in combating SARS-CoV-2, especially if the research advances demonstrate in a more substantial way the risk of transmission through contaminated water and sewage.

It is noteworthy that the lack of basic sanitation in cities and rural regions in the Amazon can increase the circulation of SARS-CoV-2 in the precarious surface and underground water supply systems, establishing the need for continuous monitoring of this pathogen in these environments, in order to predict and minimize future outbreaks of COVID-19. Barrozo et al. (2020), França (2020), Gois et al. (2020), Ribeiro et al. (2020), Rodrigues and Rodrigues (2020) and Tavares and França (2020) were unanimous in concluding about the direct relationship between the greatest socioeconomic and environmental vulnerability in the Brazilian Amazon, especially in the North Region of Brazil, with the highest incidence and mortality from COVID-19 recorded in the respective study periods. Socio-spatial discrepancies within and between regions exacerbate the risks of contagion and death in the current pandemic scenario.

\section{CONCLUSIONS}

As seen, several studies have been developed aiming to understand the pathophysiological and epidemiological behavior of SARS-CoV-2, which causes COVID-19, in an attempt to combat the advance of the pandemic. Some of these researches already demonstrate the viability of the new coronavirus in feces and urine of infected patients, even after the disappearance of symptoms and the non-detection of the virus in the respiratory tract that may indicate the possibility of fecal-oral transmission through contaminated water and sewage.

The risk of transmission by asymptomatic infections coupled with these indications raises concern about the potential spread of COVID-19, especially in socioeconomically more vulnerable areas, where basic sanitation services are precarious or non-existent, as in the Amazon, as evidenced by the data discussed throughout this study. However, we need to see the possibilities of coping that present in these circumstances. Research has proposed the monitoring of natural water and wastewater at strategic points in order to track the circulation of SARS-CoV-2 in communities without a case record, and to adopt (in positive cases) brief measures to restrict the movement of the local population, reducing the spread of the pathogen and minimizing the impact on health systems. The results of the Monitoramento Covid Esgotos project demonstrate the effectiveness of this application (INCT ETEs Sustentáveis, 2020b).

For this purpose, rapid wastewater testing methods are being proposed, such as the one developed by Mao et al. (2020). These methods are based on effective experiments used to screen for other pathogens. It is also essential that specialists in the environmental, sanitary, microbiological, health and public policy areas develop multidisciplinary and practical solutions that guarantee the safety of drinking water supply and wastewater treatment systems. This 
consequently will ensure the quality of natural aquatic environments, according to the heterogeneity of the country's regions. And more emphatically, it is necessary that these propositions have the necessary economic and political support to be implemented.

\section{REFERENCES}

Agência Nacional de Águas - ANA (2017). Atlas Esgotos: despoluição de bacias hidrográficas. Brasília: ANA. Retrieved May 21, 2020 from http://arquivos.ana.gov.br/imprensa/publicacoes/ATLASeESGOTOSDespoluicaodeBaciasHidr ograficas-ResumoExecutivo_livro.pdf.

Barrozo, L. V., Serafim, M. B., Moraes, S. L., \& Mansur, G. (2020). Monitoramento espaço-temporal das áreas de alto risco de COVID-19 nos municípios do Brasil. Hygeia, especial, 417-425, June. DOI: http://dx.doi.org/10.14393/Hygeia0054547.

Brasil (2020a). Ministério da Saúde. Cadastro Nacional de Estabelecimentos de Saúde. Número de leitos de internação. Brasília: Ministério da Saúde. Retrieved June 16, 2020 from http://tabnet.datasus.gov.br/cgi/tabcgi.exe?cnes/cnv/leiintbr.def.

Brasil (2020c). Ministério da Saúde. COVID-19 no Brasil. Brasília: Ministério da Saúde. Retrieved June 16, 2020 from https://susanalitico.saude.gov.br/\#/dashboard/.

Brasil (2020b). Ministério da Saúde. Departamento de Informática do Sistema Único de Saúde (DATASUS). Informações de Saúde (TABNET). Brasília: Ministério da Saúde. Retrieved April 11, 2020 from http://www2.datasus.gov.br/DATASUS/index.php?area=02.

Brasil (2019). Ministério do Desenvolvimento Regional. Sistema Nacional de Informações sobre Saneamento: 24 Diagnóstico de Serviços de Água e Esgoto - 2018. Brasília: SNS/MDR. Retrieved April 8, 2020 from http://www.snis.gov.br/diagnostico-anual-agua-eesgotos/diagnostico-dos-servicos-de-agua-e-esgotos-2018.

Brito, A. P., Tomasella, J., Wahnfried, I. D., Candido, L. A., Monteiro, M. T., \& Filgueiras, S. J. F. (2020). Relação entre precipitação e recarga de águas subterrâneas na Amazônia Central. Águas Subterrâneas, 34(1), 39-49. DOI: https://doi.org/10.14295/ras.v34i1.29616.

Coelho, F. C., Lana, R. M., Cruz, O. G., Villela, D., Bastos, L. S., Piontti, A. P., Davis, J. T., Vespignani, A., Codeço, C. T., \& Gomes, M. F. C. (2020). Assessing the potential impact of COVID-19 in Brazil: mobility, morbidity and the burden on the health care system. The Lancet Infectious Diseases, March 26. DOI: https://doi.org/10.1101/2020.03.19.20039131.

França, S. A. S. (2020). A importância do direito à água e ao saneamento para o combate à Covid19. Paper do NAEA, 29(1), 70-85.

Franco, A. O., \& Arcos, F. O. (2020). Vulnerabilidade natural de aquíferos e a potencial contaminação dos recursos hídricos subterrâneos no Estado do Acre. Águas Subterrâneas, 34(1), 1-11. DOI: https://doi.org/10.14295/ras.v34i1.29749.

Fundação Getúlio Vargas - FGV. (2018). Medindo o saneamento - potencialidades e limitações dos bancos de dados brasileiros. Rio de Janeiro: FGV/CERI. Retrieved May 21, 2020 from 
https://ceri.fgv.br/sites/default/files/publicacoes/2018-10/59_59_fgv-ceri-medindo-osaneamento-2018.pdf.

Gil, A. C. (2008). Métodos e técnicas de pesquisa social. São Paulo: Editora Atlas.

Gois, J. N. M., Lira, R. B. G., Oliveira Filho, R. D., Nunes, L. E., \& Oliveira, J. C. (2020). Vulnerabilidade social em tempos pandêmicos: correlação entre determinantes sociais de saúde e incidência da COVID-19 nas regiões brasileiras. Research, Society and Development, 9(9), e158996734. doi: http://dx.doi.org/10.33448/rsd-v9i9.6734.

Gormley, M., Aspray, T. J., \& Kelly, D. A. (2020). COVID-19: mitigating transmission via wastewater plumbing system. The Lancet Global Health, March 23. DOI: https://doi.org/10.1016/S2214109x(20)30112-1.

Gu, J., Han, B., \& Wang, J. (2020). COVID-19: gastrointestinal manifestations and potential fecaloral transmission. Gastroenterology, 1-2. DOI: https://doi.org/10.1053/j.gastro.2020.02.054.

Guimarães, A. F., Barbosa, V. L. M., Silva, M. P., Portugal, J. K. A., Reis, M. H. S., \& Gama, A. S. M. (2020). Acesso a serviços de saúde por ribeirinhos de um município no interior do estado do Amazonas, Brasil. Rev. Pan. Amaz. Saúde, 11, e202000178, 1-7. DOI: https://doi.org/10.5123/S2176-6223202000178.

Harmooshi, N. N., Shirbandi, K., \& Rahim, F. (2020). Environmental concern regarding the effect of humidity and temperature on SARS-CoV-2 (COVID-19) survival: fact or fiction. March 29. DOI: https://doi.org/10.2139/ssrn.3563403.

He, F., Deng, Y., \& Li, W. (2020). Coronavirus disease 2019: what we know? Journal of Medical Virology, 1-7. DOI: https://doi.org/10.1002/jmv.25766.

Holshue, M. L., Debolt, C., Lindquist, S., Lofy, K. H., Wiesman, J., Bruce, H., Spitters, C., Ericson, K., Wilkerson, S., Tural, A., Diaz, G., Cohn, A., Fox, L., Patel, A., Gerber, S. I., Kim, L., Tong, S., Lu, X., Lindstrom, S., Pallansch, M. A., Weldon, W. C., Biggs, H. M., Uyeki, T. M., \& Pillai, S. K. (2020). First case of 2019 novel coronavirus in the United States. N. Engl. J. Med., 382(10), 929-936. DOI: https://doi.org/10.1056/NEJMoa2001191.

Husman, A. M. R., \& Lodder, W. (2020). SARS-CoV-2 in wastewater: potencial health risk, but also data source. Lancet Gastroenterol. Hepatol, April 1. DOI: https://doi.org/10.1016/S24681253(20)30087-X.

Instituto Brasileiro de Geografia e Estatística - IBGE (2020a). Características gerais dos domicílios e dos moradores: 2019. Rio de Janeiro: IBGE. Retrieved May 21, 2020 from https://biblioteca.ibge.gov.br/index.php/biblioteca-catalogo?view=detalhes\&id=2101707.

Instituto Brasileiro de Geografia e Estatística - IBGE (2020b). Cidades e Estados - População Estimada 2019. Rio de Janeiro: DPE/IBGE. Retrieved April 10, 2020 from https://www.ibge.gov.br/cidades-e-estados.html?view=municipio. 
Instituto Brasileiro de Geografia e Estatística - IBGE (2017). Classificação e caracterização dos espaços rurais e urbanos do Brasil: uma primeira aproximação. Rio de Janeiro: IBGE. Retrieved May 21, 2020 from https://biblioteca.ibge.gov.br/visualizacao/livros/liv100643.pdf.

Instituto Brasileiro de Geografia e Estatística - IBGE (2020c). Pesquisa Nacional por Amostra de Domicílios Contínua 2019. Rio de Janeiro: IBGE. Retrieved May 21, 2020 from https://www.ibge.gov.br/estatisticas/sociais/populacao/17270-pnadcontinua. html ?edicao $=27258 \& \mathrm{t}=$ resultados.

Instituto Nacional de Ciência e Tecnologia em Estações Sustentáveis de Tratamento de Esgoto INCT ETEs Sustentáveis (2020a). Monitoramento Covid Esgotos: Boletim de Acompanhamento no. 4. Belo Horizonte: INCT/ANA, June 5. Retrieved June 16, 2020 from https://www.ana.gov.br/noticias/percentual-de-amostras-com-coronavirus-segue-alto-nasexta-semana-de-pesquisa-mas-mostra-leve-queda-na-bacia-do-onca/boletim-04_8-dejunho-de-2020_-monitoramento-covid-esgotos.pdf.

Instituto Nacional de Ciência e Tecnologia em Estações Sustentáveis de Tratamento de Esgoto INCT ETEs Sustentáveis (2020b). Monitoramento Covid Esgotos: Boletim de Acompanhamento no. 13. Belo Horizonte: INCT/ANA, Aug. 28. Retrieved Sept. 04, 2020 from https://www.ana.gov.br/panorama-das-aguas/qualidade-da-agua/boletins-monitoramentocovid-esgotos/boletim-de-acompanhamento-no-132020.pdf.

Instituto de Pesquisa Econômica Aplicada - Ipea (2013). Índice de Desenvolvimento Humano Municipal Brasileiro. Brasília: PNUD; Ipea; FJP. Retrieved April 10, 2020 from https://www.br.undp.org/content/brazil/pt/home/library/idh/o-idh-brasileiro0.html.

Instituto Trata Brasil - ITB (2020). Recomendações para prevenção do contágio da COVID-19 (novo coronavírus - SARS-CoV-2) pela água e por esgoto doméstico. São Paulo: ITB. Retrieved April 7, 2020 from http://tratabrasil.org.br/covid-19/assets/pdf/cartilha_covid-19.pdf.

Jardim, V. C. \& Buckeridge, M. S. (2020). Análise sistêmica do município de São Paulo e suas implicações para o avanço dos casos de Covid-19. Estudos Avançados, 34(99), 157-174.

Le Tourneau, F. M., Marchand, G., Gamez, L., Tritsch, I., \& Arvor. D. (2019). Mudanças e permanências na trajetória rumo à sustentabilidade: uma imagem compósita da Amazônia. In F. M. Le Tourneau \& O. Canto (Orgs.), Amazônias brasileiras, situações locais e evoluções (pp. 19-64). Belém: NNUMA/UFPA.

Lipsitch, M., Swerdlow, D, L., \& Finelli, L. (2020). Defining the epidemiology of Covid-19 - studies needed. N. Engl. J. Med., 382(13), 1194-1196, March 26. DOI: https://doi.org/10.1056/NEJMp2002125.

Lobão, M. (2020). Amazônia rural brasileira: aspectos sociodemográficos. Revista de Geografia e Ordenamento do Território, 17, 123-150, June. DOI: https://doi.org/10.17127/got/2019.17.006.

Lodder, W. J., Rutjes, S. A., Takumi, K., \& Husman, A. M. R. (2013). Aichi virus in sewage and surface water, the Netherlands. Emerg. Infect. Dis., 19, 1222-1230. DOI: https://doi.org/10.3201/eid1908.130312. 
Macedo, Y. M., Ornellas, J. L., \& Bomfim, H. F. (2020). COVID-19 no Brasil: o que se espera para população subalternizada? Revista Encantar, Bom Jesus da Lapa, 2, 1-10, Jan./Dec. DOI: https://doi.org/10.5935/encantar.v2.0001.

Mao, K., Zhang, H., Yang, Z. (2020). Can a paper-based device trace COVID-19 sources with wastewater-based epidemiology? Environ. Sci. Technol., 54, 3733-3735. DOI: https://doi.org/10.1021/acs.est.0c01174.

Melo, M. C., Santos, A. S. P., \& Vieira, J. M. P. (2020). A nova centralidade da água e do saneamento pós-COVID-19. Rev. Augustus, 25(51), 294-315, July/Oct.

Meng, X., Huang, X., Zhou, P., Li, C., \& Wu, A. (2020). Alert for SARS-CoV-2 caused by fecal aerosols in rural areas in China. Infection Control \& Hospital Epidemiology, 1-4, April. DOI: https://doi.org/10.1017/ice.2020.114.

Mourão, K. A. C. \& Silva, S. F. M. (2018). Reflexões acerca do desenvolvimento da Amazônia no século XXI. Belém: Editora Folheando.

Naddeo, V. \& Liu, H. (2020). 2019 novel coronavírus (SARS-CoV-2): what is its fate in urban water cycle and how can water research community respond? Environ. Sci. Water Res. Technol., 4, March 27. DOI: https://doi.org/10.1039/D0EW90015J.

Nascimento, F. L. (2020). Cemitério x novo coronavírus: impactos da COVID-19 na saúde pública e coletiva dos mortos e dos vivos. Boletim de Conjuntura, Boa Vista, 2(4), 1-9.

Neu, V., Santos, M. A. S., \& Meyer, L. F. F. (2016). Banheiro ecológico ribeirinho: saneamento descentralizado para comunidades de várzea na Amazônia. Em Extensão, Uberlândia, 15(1), 28-44, Jan./June.

Pantojo, F., Salimena, T., Castro, S., \& Dias, E. (2019). Evolução do saneamento básico no Brasil: uma análise crítica dos serviços de água e esgoto com base na experiência do SNIS. REUCP, Petrópolis, 13(1), 16-25.

Pereira, L. L., Lopes, R. M., Santos, D., Figueiredo, M. A. G., \& Santana, E. G. S. (2020). Saneamento e saúde pública sob a perspectiva da população local: estudo de caso do município de Altamira-PA, após a implantação da usina hidrelétrica de Belo Monte. Braz. J. of Develop., Curitiba, 6(2), 9592-9602, February. DOI: https://doi.org/10.34117/bjdv6n2-318.

Portugal, R. (2018). O retorno dos que nunca foram: propostas para instituições de desenvolvimento regional. In K. A. C. Mourão \& S. F. M. Silva (Orgs.), Reflexões acerca do desenvolvimento da Amazônia no século XXI (pp. 143-162). Belém: Editora Folheando.

Portugal, R. \& Silva, S. F. M. (2018). Política Nacional de Desenvolvimento Regional na Amazônia: dilemas, desafios e oportunidades. In K. A. C. Mourão \& S. F. M. Silva (Orgs.), Reflexões acerca do desenvolvimento da Amazônia no século XXI (pp. 19-42). Belém: Editora Folheando.

Repici, A., Maselli, R., Colombo, M., Gabbiadini, R., Spadaccini, M., Anderloni, A., Carrara, S., Fugazza, A., Di Leo, M., Galtieri, P. A., Pellegatta, G., Ferrara, E. C., Azzolini, E., \& Lagioia, M. 
(2020). Coronavirus (COVID-19) outbreak: what the department of endoscopy should know. Gastrointestinal Endoscopy, 1-6. DOI: https://doi.org/10.1016/j.gie.2020.03.019.

Ribeiro, H., Lima, V. M. L., \& Waldman, E. A. (2020). In the COVID-19 pandemic in Brazil, do brown lives matter? The Lancet Global Health, 8, 976-977, July. DOI: https://doi.org/10.1016/S2214109x(20)30314-4.

Rodrigues, J. C. \& Rodrigues, J. C. (2020). Condições de desigualdades e vulnerabilidades socioespaciais em cidades da Amazônia paraense: elementos promovedores da expansão e dispersão da COVID-19? Hygeia, especial, 132-142, June.

Rodriguez-Morales, A. J., Gallego, V., Escalera-Antezana, J. P., Mendez, C. A., Zambrano, L. I., Franco-Paredes, C., Suárez, J. A., Rodriguez-Enciso, H. D., Balbin-Ramon, G. J., Savio-Larriera, E., Risquez, A., \& Cimerman, S. (2020). COVID-19 in Latin America: The implications of the first confirmed case in Brazil. Travel Medicine and Infectious Disease. DOI: https://doi.org/10.1016/j.tmaid.2020.101613.

Rothe, C., Schunk, M., Sothmann, P., Bretzel, G., Froeschl, G., Wallrauch, C., Zimmer, T., Thiel, V., Janke, C., Guggemos, W., Seilmaier, M., Drosten, C., Vollmar, P., Zwirglmaier, K., Zange, S., Wölfel, R., \& Hoelscher, M. (2020). Transmission of 2019-nCoV infection from an asymptomatic contact in Germany. N. Engl. J. Med., 382(10), March 5. DOI: https://doi.org/10.1056/NEJMc2001468.

Sahin, A. R., Erdogan, A., Agaoglu, P. M., Dineri, Y., Cakirci, A. Y., Senel, M. E., Okyay, R. A., \& Tasdogan, A. M. (2020). 2019 novel coronavirus (COVID-19) outbreak: a review of the current literature. Eurasian Journal of Medicine and Oncology, 4(1), 1-7. DOI: https://doi.org/10.14744/ejmo.2020.12220.

Santiago, E. P., Cartaxo, E. F., Rabelo Filho, J. G. F., Nogueira, L. D., \& Souza, P. R. (2019). Desenvolvimento de banco de dados geográficos priorizando o uso de softwares gratuitos para gestão de reservatórios de hidrelétricas na Amazônia. Braz. J. of Develop., Curitiba, 5(7), 85108521, July. DOI: https://doi.org/10.34117/bjdv5n7-065.

Silva, E. S., Oliveira, D. D., \& Lopes, A. P. (2019). Acesso ao saneamento básico e incidência de cólera: uma análise quantitativa entre 2010 e 2015. Saúde Debate, Rio de Janeiro, 43(especial), 121-136, December. DOI: https://doi.org/10.1590/0103-11042019S309.

Silva, S. A. (2015). A PNDR e o planejamento regional brasileiro no início do século XXI. Brasília: $\begin{array}{lllll}\text { Ipea. } & \text { Retrieved } & \text { April } & 10, & \end{array}$ http://repositorio.ipea.gov.br/bitstream/11058/6485/1/td_2150.pdf.

Sohrabi, C., Alsafi, Z., O’Neill, N., Khan, M., Kerwan, A., Al-Jabir, A., losifidis, C., \& Agha, R. (2020). World Health Organization declares global emergency: a review of the 2019 novel coronavirus (COVID-19). International Journal of Surgery, 76, 71-76. DOI: https://doi.org/10.1016/j.ijsu.2020.02.034.

Superintendência do Desenvolvimento da Amazônia - SUDAM (2020). Plano Regional de Desenvolvimento da Amazônia (PRDA) 2020-2023. Belém: SUDAM. Retrieved April 10, 2020 
from

http://www.sudam.gov.br/conteudo/menus/retratil/planosdesenvolvimento/prda/arquivos/prda-2020-2023.pdf.

Tavares, A. C. P. \& França, S. A. S. (2020). A COVID-19 e os desafios da urbanização e habitabilidade nas cidades amazônicas: estudo de caso em Belém do Pará. Paper do NAEA, 29(1), 120-141.

Van Doremalen, N., Bushmaker, T., Morris, D. H., Holbrook, M. G., Gamble, A., Williamson, B. N., Tamin, A., Harcourt, J. L., Thornburg, N. J., Gerber, S. I., Lloyd-Smith, J. O., Wit, E., \& Munster, V. J. (2020). Aerosol and surfaces stability of SARS-CoV-2 as compared with SARS-CoV-1. N. Engl. J. Med., March 17. DOI: https://doi.org/10.1056/NEJMc2004973.

Varela, A. W. P., Noronha Filho, F. A., Mesquita, K. F. C., Sousa, P. H. C., Souza, A. J. N., \& Santos, M. L. S. (2020). Saneamento básico em municípios da região Amazônica (Brasil). Research, Society and Development, 9(3), 1-13. DOI: https://doi.org/10.33448/rsd-v9i3.2570.

Velavan, T. P. \& Meyer, C. G. (2020). The COVID-19 epidemic. Tropical Medicine and International Health, 25(3), 278-280, March. DOI: https://doi.org/10.1111/tmi.13383.

Wang, J., Tang, K., Feng, K., \& Lv, W. (2020). High temperature and high humidity reduce the transmission of COVID-19. SSRN, 1-9, March 9. DOI: https://doi.org/10.2139/ssrn.3551767.

World Health Organization - WHO (2020). Water, sanitation, hygiene, and waste management for the COVID-19 virus. March 19. Retrieved April 7, 2020 from https://www.who.int/publications-detail/water-sanitation-hygiene-and-waste-managementfor-covid-19.

Wu, Y. C., Chen, C. S., \& Chan, Y. J. (2020a). The outbreak of COVID-19: an overview. Journal of Chinese Medical Association, 83, 217-220. DOI: https://doi.org/10.1097/JMCA.0000000000000270.

Wu, Y., Guo, C., Tang, L., Hong, Z., Zhou, J., Dong, X., Yin, H., Xiao, Q., Tang, Y., Qu, X., Kuang, L., Fang, X., Mishra, N., Lu, J., Shan, H., Jiang, G., \& Huang, X. (2020b). Prolonged presence of SARS-CoV-2 viral RNA in faecal samples. Lancet Gastroenterol. Hepatol., March 19. DOI: https://doi.org/10.1016/S2468-1253(20)30083-2.

Yeo, C., Kaushal, S., \& Yeo, D. (2020). Enteric involvement of coronaviruses: is faecal-oral transmission of SARS-CoV-2 possible? Lancet Gastroenterol. Hepatol., 5(4), 335-337, April. DOI: https://doi.org/10.1016/S2468-1253(20)30048-0.

\section{COMO CITAR ESTE ARTIGO:}

Costa, J. S. da., Rodrigues, L. de S., Silva, A. G. C. da, Neto, R. A., Batista, I. H., Albuquerque, C. C. de, Melo, M. da G. G. de, Liberato, M. A. R. (2020). Water, sanitation and Covid-19 in the Amazon. Holos. 36(5), 1-23.

\section{SOBRE OS AUTORES}

\section{J. S. DA COSTA}

Mestrando em Gestão e Regulação de Recursos Hídricos - PROFÁGUA, pela Universidade do Estado do Amazonas - UEA. Graduado em Ciências Biológicas, pela Universidade do Estado da Bahia - UNEB.

E-mail: jamersonjsc@yahoo.com.br 
ORCID ID: https://orcid.org/0000-0001-5318-2213

\section{DE S. RODRIGUES}

Mestranda em Gestão e Regulação de Recursos Hídricos e Graduada em Geografia, pela Universidade do Estado do Amazonas - UEA.

E-mail: li rodriguess212@hotmail.com

ORCID ID: https://orcid.org/0000-0001-9014-8241

\section{A. G. C. DA SILVA}

Mestranda em Gestão e Regulação de Recursos Hídricos, pela Universidade do Estado do Amazonas - UEA; Especialista em Perícia, Auditoria e Gestão Ambiental, pelo Centro Universitário do Norte - UNINORTE; Graduada em Engenharia Química, pela Universidade do Estado do Amazonas - UEA.

E-mail: alinegabriela@hotmail.com

ORCID ID: https://orcid.org/0000-0002-4273-370X

\section{R. A. NETO}

Mestrando em Gestão e Regulação de Recursos Hídricos e Graduado em Saneamento Ambiental, pela Universidade do Estado do Amazonas - UEA.

E-mail: ruben.neto@gmail.com

ORCID ID: https://orcid.org/0000-0002-8743-5343

\section{H. BATISTA}

Pós-doutora em Educação Ambiental, pela Universidade Federal do Ceará - UFC; Doutora em Biotecnologia, Mestre em Ciências do Ambiente e Sustentabilidade na Amazônia, Especialista em Biotecnologia para o Desenvolvimento Sustentável e Graduada em Ciências Biológicas, pela Universidade Federal do Amazonas - UFAM; Docente do Programa de Mestrado Profissional em Gestão e Regulação dos Recursos Hídricos, da Universidade do Estado do Amazonas - UEA.

E-mail: iedahbatista@gmail.com

ORCID ID: https://orcid.org/0000-0001-8465-3129

\section{C. DE ALBUQUERQUE}

Doutor em Geografia, pela Universidade Federal do Ceará - UFC; Mestre em Ciências do Ambiente e Sustentabilidade na Amazônia, Especialista em Engenharia Ambiental e Graduado em Geografia, pela Universidade Federal do Amazonas - UFAM; Coordenador do Programa de Mestrado Profissional em Gestão e Regulação de Recursos Hídricos, da Universidade do Estado do Amazonas - UEA.

E-mail: carlossandro.albuquerque@gmail.com

ORCID ID: https://orcid.org/0000-0001-8399-6170

\section{DA G. G. DE MELO}

Doutora em Agronomia Tropical, Mestre em Ciências Agrárias, pela Universidade Federal do Amazonas UFAM; Graduada em Engenharia Florestal, pelo Instituto de Tecnologia da Amazônia; Vice-Coordenadora do Programa de Mestrado Profissional em Gestão e Regulação de Recursos Hídricos, da Universidade do Estado do Amazonas - UEA.

E-mail: gloriamelo@yahoo.com

ORCID ID: https://orcid.org/0000-0001-8446-5021

\section{A. R. LIBERATO}

Doutora e Mestre em Ciências Biológicas pelo Instituto Nacional de Pesquisas da Amazônia - INPA; Graduada em Ciências Biológicas e Administração, pela Universidade Federal do Amazonas - UFAM; Docente do Programa de Mestrado Profissional em Gestão e Regulação de Recursos Hídricos, da Universidade do Estado do Amazonas - UEA.

E-mail: astrid.liberato@gmail.com 
ORCID ID: https://orcid.org/0000-0002-6750-7303

Editor(a) Responsável: Francinaide Nascimento e Leandro Costa

Pareceristas Ad Hoc: Kenio Lima e Ermeton do Nascimento

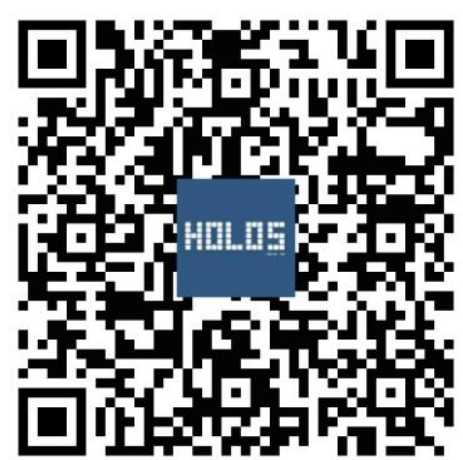

